\title{
Microfluidic Manufacture of Solid Lipid Nanoparticles: A case study on tristearin-based systems
}

\author{
Giulia Anderluzzi and Yvonne Perrie*
}

Strathclyde Institute of Pharmacy and Biomedical Sciences, University of Strathclyde, Glasgow G4 ORE

*Corresponding author

\begin{abstract}
Solid lipid nanoparticles are lipid-based carriers and that can be used for a range of drugs and biomolecules. However, most manufacturing methods currently used do not offer easy translation from laboratory to scale-independent production. Within this study, we have investigated the use of microfluidics to produce solid lipid nanoparticles and investigated their protein loading capability. In the development of the process we have investigated and identified the critical process parameters that impact on the production of the SLNs. Solid lipid nanoparticles based on Tristearin and 1,2Distearoyl-phosphatidylethanolamine-methyl-polyethyleneglycol conjugate-2000 were formulated using on the Nanoasemblr ${ }^{\circledR}$ Benchtop system from Precision Nanosystems and the flow rate ratio and total flow rate were investigated as process parameters and the particle size, PDI, zeta potential, drug loading and drug release was quantified. Our results demonstrate the suitability of microfluidics as a valid method for solid lipid nanoparticles containing protein production. In terms of key process parameters to consider, both the solvent/aqueous ratio (FRR) and total flow rate were shown to have a notable impact on particle size. However, protein loading capacity was similar across all flow rates tested. Within this study we outline a rapid and easy to adopt protocol for the scale-independent production of solid lipid nanoparticles and this process can support the rapid translation of production methods from bench to clinic.
\end{abstract}

Key Words: $\quad$ Solid lipid nanoparticles, Nanoassemblr, Microfluidics, protein delivery 


\section{Introduction}

Microfluidics technology is based on controlled manipulation and mixing of fluids in the microliter to picolitre range. Since its first application in the 1980s, ${ }^{(1)}$ microfluidics has emerged as lab-on-a-chip based technology for process development ${ }^{(2-3)}$, to automate laboratory procedures in the fields of pharmaceutical industry and biotechnology ${ }^{(4)}$ and to produce nanomedicines ${ }^{(5-9)}$. Indeed, the rise in the number of publications on PubMed referencing microfluidic* is shown in Figure 1 and can be seen to have grown to approximately 2500 since 1988. In general, microfluidics involves the controlled mixing of fluids, with fluid mixing being dictated by the design of the microfluidic cartridge (with numerous formats and mixing-steps having been investigated) and the process parameters adopted (including the flow rate through the cartridge and the mixing ratios employed during the process). In terms of a mixing process, microfluidics offers a range of advantages including scalable working volumes from very low volumes to high-throughput, short reaction times, reduced cost, controlled mixing and enhanced parameter control combined with process automation ${ }^{(10-13)}$. Due to these advantages, microfluidics has been used to produce a range of nanoparticle systems including lipid nanoparticles, liposomes, polymeric nanoparticles and solid lipid nanoparticles with some examples outlined in Table 1. By using microfluidics to rapidly mix liquids of different polarities nanoprecipitation of dissolved molecules can be promoted to produce uniform nanoparticle suspensions. ${ }^{(40)}$

As shown in Table 1, the majority of the investigations looking at manufacturing with microfluidics has focused on the production of liposomes with less consideration given to solid lipid nanoparticles (SLNs). This may be due to solid lipid nanoparticles being less widely studied as potential delivery systems with a PubMed search identifying only around 200 publications associated with these systems (Figure 1). As delivery systems, solid lipid nanoparticles can offer a range of advantages including high stability in body fluids and tissues, sustained drug release, biodegradability, ease of manufacture and the capacity to scale up to industrial production levels at relatively low cost. ${ }^{(41-43)}$ In terms of their application, SLNs are most commonly explored as solubilising agents for the delivery of poorly soluble drugs, due to the hydrophobic nature of the particles matrix. However, they have also been investigated for the delivery of nucleic acids ${ }^{(44)}$, proteins, antigens, or in food industry ${ }^{(45-46)}$ as carriers for bioactive compounds or to protect biomolecules against degradation. A particular area of interest within our research laboratories is in the development of novel adjuvants. Studies have demonstrated that SLNs have an adjuvant activity and the intensity is related to the size; particles with a diameter of more than $100 \mathrm{~nm}$ exhibited a clear adjuvant activity, whereas SLNs with size below $100 \mathrm{~nm}$, in various concentrations, revealed a lower adjuvant activity. ${ }^{(47-48)}$ Furthermore, SLNs in association with interleukin 2 have been shown to increase antibody titre, spleenocyte proliferation, and secretion of interferon-gamma and interleukin 4 cytokines. ${ }^{(49)}$ The adjuvant effect of SLNs is related to their ability to protect sub-unit antigens from rapid degradation in vivo, and to promote delivery and targeting of antigen presenting cells ${ }^{(50)}$.

In terms of manufacturing processes, high-pressure homogenization ${ }^{(51)}$ and microemulsion-based techniques ${ }^{(52-53)}$ are the most used methods in the preparation of SLNs. However, these methods have limitations such as poor drug loading capacity, drug expulsion after polymeric transition during storage and relatively high-water content of the dispersions ${ }^{(54)}$. Furthermore, the drug loading capacity of conventional SLNs is limited by the solubility of drug in the lipid melt, the structure of the lipid matrix and the polymeric state of the lipid matrix. If the lipid matrix consists of similar molecules (i.e. 
tristearin or tripalmitin), a perfect crystal with few imperfections is formed. Since incorporated drugs are located between fatty acid chains, between the lipid layers and in crystals imperfections, a highly ordered structure can reduce drug loading. Given the potential of microfluidics to produce nanoparticles, herein we consideration the application of microfluidics for rapid and scale independent manufacture of solid lipid nanoparticles. To achieve this, we investigate the process parameters involved in their microfluidic production and consider the loading of protein within these systems.

\section{Materials and Methods}

\subsection{Materials}

Tristearin (Grade II-S, $\geq 90 \%$ ) and trifluoracetic acid (TFA) were obtained from Sigma-Aldrich Company Itd, Poole, UK. 1,2-Distearoyl-phosphatidylethanolamine-methyl-polyethyleneglycol conjugate-2000 (DSPE-mPEG-2000) was obtained from Lipoid GmbH (Ludwigshafen Germany). Ethanol were obtained from Fisher 141 Scientific UK, Loughborough, UK. TRIS Ultra-Pure was obtained from ICN 142 Biomedicals, Inc., Aurora, Ohio. Phosphate-buffered saline (PBS) and Albumin from chicken egg (OVA), were obtained from Sigma-Aldrich Company Itd, Poole, UK. Sephadex G-75 size exclusion columns were obtained from GE Healthcare Life Science -Little Chalfont-Buckinghamshire, UK.

\subsection{Preparation of solid lipid particles using Nanoassemblr platform}

Solid lipid nanoparticles formulations using the micromixer were performed on a benchtop NanoAssemblr ${ }^{\mathrm{TM}}$ instrument (NanoAssemblr ${ }^{\mathrm{TM}}$, Precision Nano- Systems Inc.). The two inlet streams comprised lipids dissolved in ethanol and aqueous buffer (Tris, $10 \mathrm{mM}, \mathrm{pH}$ 7.4), syringe pumps allowed for controlling the flow rates and the flow ratios between the two inlet streams. Solid lipid nanoparticles were prepared with the Nanoassemblr ${ }^{\mathrm{TM}} ; 1.3 \mathrm{mg}$ of Tristearin $0.25 \mathrm{mg}$ of mPEG-DSPE were dissolved in $1 \mathrm{~mL}$ of ethanol $\left(70^{\circ} \mathrm{C}\right.$ ) and OVA (when added) was dissolved in $1 \mathrm{~mL}$ TRIS buffer $\mathrm{pH}$ $7.410 \mathrm{mM}$. Both solutions mixed via microfluidics and particles were collected in a 15-mL falcon tube. The total flow rate (TFR) was varied between 5 and $20 \mathrm{~mL} /$ and the aqueous/solvent ratio (FRR) was varied between $1: 1,3: 1$ and $5: 1$.

\subsection{Solvent purification methods}

To consider solvent purification methods, residual solvent levels were quantified after tangential Flow Filtration (TFF - KR2i TFF System ${ }^{\circledR}$ - Filtration speed $27 \mathrm{~mL} / \mathrm{min}$, washing volume $20 \mathrm{~mL}$ ), dialysis (1hour, membrane cut off $14000 \mathrm{KDa}$ ) and spin column ( $3 \mathrm{~mL}$ elution buffer volume). Residual solvent was detected using gas chromatography (GC-MS, Agilent Technologies) adding 1\% 2-propanol (IPA) as internal standard; peaks area was normalised by IPA peak area and related to solvent concentration through a calibration curve with a linearity of $R^{2}=0.9502$. All measurements were within the level of detection and level of quantification.

\subsection{Lipid recovery quantification after purification}

Lipid recovery after dialysis, TFF and spin column was performed by adding 1,1'-Dioctadecyl-3,3,3',3'Tetramethylindocarbocyanine Perchlorate (DilC) $0.2 \%$ mol total lipid concentration solved in ethanol to lipid stocks before being loaded in the Nanoassemblr. DilC fluorescence was measured before and after TFF, dialysis and spin column (PolarStar, BMG LABTECH GmbH). Lipid quantification was achieved 
by referring to a calibration curve with a linearity of $R^{2}=0.995$. All measurements were within the level of detection and level of quantification.

\subsection{Characterisation of SLNs}

The dynamic light scattering (DLS) technique was used to report the intensity mean diameter (zaverage) and the polydispersity of all solid lipid nanoparticles formulations (Malvern Zetasizer NanoZS (Malvern Instruments, Worcs., UK). Particles size and polydispersity analysis was carried out at 25 ${ }^{\circ} \mathrm{C}$ in Tris buffer (10 mM, pH 7.4). Liposome zeta potential was measured in Tris buffer $(10 \mathrm{mM}, \mathrm{pH}$ 7.4) using the Malvern Zetasizer Nano-ZS (Malvern Instruments, Worcs., UK).

\subsection{Protein loading quantification.}

The loading efficiency was measured using reverse phase HPLC (Agilent 1100 Series) with a mobile phase of TFA $0.1 \%$ and methanol with $0.08 \%$ TFA with a flow rate of $2.0 \mathrm{~mL} / \mathrm{min}, \lambda \max$ of $215 \mathrm{~nm}$. At these conditions the OVA retention time is $9.6 \mathrm{~min}$. The particles were destroyed using a solution of IPA: TRIS 50:50 vol/vol. The solution was left at room temperature for 1 hour to achieve the complete particle dissolution. All measurements were within the level of detection and level of quantification.

\subsection{In vitro release study}

For the release study of $0.5 \mathrm{mg} / \mathrm{mL}$ ovalbumin from SLNs, nanoparticles were prepared using Nanoassemblr (TFR $10 \mathrm{~mL} / \mathrm{min}$, FRR 3:1) as previously described. All formulations were dialysed against $80 \mathrm{~mL} \mathrm{PBS} \mathrm{pH} 7.4$ at $37^{\circ} \mathrm{C}$ (membrane cut off $300 \mathrm{KDa}$ ). The absorbance of aliquots from the outer buffer was analysed at different time points $(0.25,0.5,0.75,1,1.5,2,4,6,8,10,12,24$ and 48 h) using NanoDrop 2000c UV-Vis spectrophotometer (Thermo Fisher Scientific Inc). OVA release was detected by measuring the protein absorbance at $230 \mathrm{~nm}$ (NanoDrop 2000c, UV-Vis Spectrophotometer).

\subsection{Statistical analysis}

Unless stated otherwise, the results were calculated as mean \pm standard deviation (SD) from three independent studies. ANOVA followed by Tukey post hoc analysis was performed for comparison and significance was acknowledged for $p$ values less than 0.05 . All the calculations were made using Excel (Excel Software and Systems Pvt. Ltd.).

\section{Results}

\subsection{SLNs manufacturing by microfluidics- particles size can be in process controlled}

Solid lipid nanoparticles consisting OF Tristearin and PEG-DSPE were prepared using the microfluidics method and the aim of this study was to evaluate how process parameters changes impact on particles size and polydispersity. More precisely the percentage of organic phase was reduced from $50 \%$ to $17 \%$ and differences in particles attributes were evaluated. Figure 2A showed the effect of modifying flow rate ratio (FRRs; ratio between organic and aqueous phase) on SLNs size distribution; by enhancing the FRR from 1:1 to $3: 1$, the diameter was reduced from $180 \pm 65 \mathrm{~nm}$ to $65 \pm 23 \mathrm{~nm}$, reaching a plateau at FRR 5:1 $(59 \pm 17 \mathrm{~nm})$. In contrast, the polydispersity index tended to increase with increasing water/solvent ratio from $1: 1$ to $3: 1$, the PDI value went from $0.17 \pm 0.09$ to $0.25 \pm 0.03$, with no significant difference for the 5:1 formulation (0.28 \pm 0.02 ). Despite this slight increase, PDI remained 
low, proving that, decreasing the organic phase from 50 to $17 \%$ did not affect samples homogeneity. This fact was confirmed by the intensity plots showed in figure $2 \mathrm{~B}$ : single narrow peaks in the graph demonstrated that the size distribution was very low despite and particles population was homogeneous among all the FRR tested. Regarding particles charge, the zeta potential values seemed to be independent from the FRR increase (Figure $2 \mathrm{C}$ ): among all aqueous/solvent ratio tested, the surface charge remained slightly negative (between -17 and $-20 \mathrm{mV}$ ) as expected, with no significant differences among FRRs tested.

\subsection{Purification process for SLNs produced by microfluidics}

Given that after microfluidics samples contain organic solvent, several purification methods were investigated. Therefore, Tristearin: mPEG-DSPE SLNs were prepared using microfluidics at a FRR 1:1; in these conditions the concentration of ethanol in the final sample is $50 \%$, thus aiming to challenge all purification systems tested. To remove solvent content from the formulations dialysis, tangential flow filtration (TFF) and spin column were employed and SLN recovery and residual solvent levels compared (Figure 3). As it shown in figure 3A, using both spin column and dialysis it was possible to collect almost $100 \%$ of initial lipids, in contrast recovery of SLNs after TFF purification was lower (72\%; Figure $3 \mathrm{~A})$. Despite the recovery values, figure 3B showed that all three methods tested could efficiently remove the organic solvent from the sample, with a residual ethanol amount between 0.5 and $0.25 \%$, in line with $\mathrm{ICH}$ guidelines for residual solvent levels.

\subsection{Protein-loaded lipid particles production using Nanoassemblr: loading efficiency as a function of manufacture process}

Using these optimised parameters, the next stage was to evaluate the suitability of microfluidics as a valid method for producing SLNs containing proteins. To consider this, three different protein (OVA) concentrations were used and loading compared. Initially, the extraction process was optimised and drug loading was measured at different time points ( 0 hours, 6 hours and 24 hours post digestion) and correlated to the corresponding concentration using a calibration curve. Spin column was applied for both solvent and free protein removal. Figure 4A shows that subjecting the OVA-loaded SLNs to prolonged exposure to IPA: TRIS 50:50 vol/vol resulted in reduced protein loading, which may be a result of protein degradation in the IPA. Therefore, for all further studies, all formulations were subjected to no more than $30 \mathrm{~min}$ digestion. Figure 4A also shows the effect of initial OVA concentration on loading capacity; as expected with increasing initial OVA concentrations the SLNs can incorporate higher concentrations up to approximately $140 \mathrm{\mu g} / \mathrm{mL}$ when initial concentrations of $1 \mathrm{mg} / \mathrm{mL}$ OVA is used. When expressed as \% loading efficiency, the maximum that can be achieved is $36 \%$ when an initial concentration of $0.1 \mathrm{mg} / \mathrm{mL}$ OVA is used (Figure 4B), and in terms of loading capacity (protein/lipid wt/wt) the trend again shows increasing loading with increasing initial OVA concentrations with up to $11 \%$ (Figure $4 \mathrm{C}$ ). Therefore, high protein loading (12\%) can be achieved when high initial protein concentrations are used but this is at the expense of loading efficacy (Figure 4).

\subsection{Influence of flow rate on particle characteristics and drug loading}

To consider the impact of production speed of the SLNs, changes in TFR on protein loaded particles attributes were further investigated. The total flow rate values were varied from $5 \mathrm{~mL} / \mathrm{min}$ to 20 $\mathrm{mL} / \mathrm{min}$, while the ratio between aqueous and solvent stream was maintained constant at 3:1. Figure $5 \mathrm{~A}$ shows the effect of flow rate changes on particles size and polydispersity. Increasing the injection 
Table 1. Examples of research investigating the use of microfluidics technology for the manufacture of nanoparticles.

\begin{tabular}{|c|c|c|c|}
\hline Title & Application & Year & Ref \\
\hline $\begin{array}{l}\text { Microfluidic Production of Alginate Hydrogel Particles } \\
\text { for Antibody Encapsulation and Release }\end{array}$ & $\begin{array}{l}\text { Alginate Hydrogel } \\
\text { Particles }\end{array}$ & 2015 & 14 \\
\hline $\begin{array}{l}\text { Controlled and tunable polymer particles' production } \\
\text { using a single microfluidic device }\end{array}$ & $\begin{array}{l}\text { Polymeric } \\
\text { nanoparticles }\end{array}$ & 2018 & 15 \\
\hline $\begin{array}{l}\text { Chemotherapy drugs derived nanoparticles } \\
\text { encapsulating mRNA encoding tumor suppressor } \\
\text { proteins to treat triple-negative breast cancer }\end{array}$ & Lipid nanoparticle & 2019 & 16 \\
\hline $\begin{array}{l}\text { MicroRNAs Enable mRNA Therapeutics to Selectively } \\
\text { Program Cancer Cells to Self-Destruct }\end{array}$ & Lipid nanoparticle & 2018 & 17 \\
\hline $\begin{array}{l}\text { A Single Administration of CRISPR/Cas9 Lipid } \\
\text { Nanoparticles Achieves Robust and Persistent In Vivo } \\
\text { Genome Editing }\end{array}$ & Lipid nanoparticles & 2018 & 18 \\
\hline $\begin{array}{l}\text { High-throughput manufacturing of size-tuned } \\
\text { liposomes by a new microfluidics method using } \\
\text { enhanced statistical tools for characterization }\end{array}$ & Liposomes & 2014 & 5 \\
\hline $\begin{array}{l}\text { Microfluidic-controlled manufacture of liposomes for } \\
\text { the } \\
\text { solubilisation of a poorly water soluble drug }\end{array}$ & Liposomes & 2015 & 6 \\
\hline $\begin{array}{l}\text { Rapid and scale-independent microfluidic } \\
\text { manufacture of liposomes entrapping protein } \\
\text { incorporating in-line purification and at-line size } \\
\text { monitoring }\end{array}$ & Liposomes & 2019 & 7 \\
\hline $\begin{array}{l}\text { Formation and purification of tailored liposomes for } \\
\text { drug delivery using a module-based micro } \\
\text { continuous-flow system }\end{array}$ & Liposomes & 2017 & 8 \\
\hline $\begin{array}{l}\text { Microfluidics based manufacture of liposomes } \\
\text { simultaneously entrapping hydrophilic and lipophilic } \\
\text { drugs }\end{array}$ & Liposomes & 2016 & 9 \\
\hline $\begin{array}{l}\text { Liposome production by microfluidics: potential and } \\
\text { limiting factors }\end{array}$ & Liposomes & 2016 & 19 \\
\hline $\begin{array}{l}\text { Microfluidic manufacturing of phospholipid } \\
\text { nanoparticles: Stability, encapsulation efficacy, and } \\
\text { drug release }\end{array}$ & Liposomes & 2016 & 20 \\
\hline $\begin{array}{l}\text { Microfluidic synthesis of multifunctional liposomes } \\
\text { for tumour targeting }\end{array}$ & Liposomes & 2016 & 21 \\
\hline $\begin{array}{l}\text { Imidazole Ketone Erastin Induces Ferroptosis and } \\
\text { Slows Tumor Growth in a Mouse Lymphoma Model }\end{array}$ & $\begin{array}{l}\text { Polymeric } \\
\text { nanoparticles }\end{array}$ & 2019 & 22 \\
\hline
\end{tabular}




\begin{tabular}{|c|c|c|c|}
\hline $\begin{array}{l}\text { Microfluidic Production and Application of Lipid } \\
\text { Nanoparticles for Nucleic Acid Transfection }\end{array}$ & Lipid nanoparticles & 2018 & 23 \\
\hline $\begin{array}{l}\text { Rapid transport of deformation-tuned nanoparticles } \\
\text { across biological hydrogels and cellular barriers }\end{array}$ & $\begin{array}{l}\text { Polymeric } \\
\text { nanoparticles }\end{array}$ & 2018 & 24 \\
\hline $\begin{array}{l}\text { The Use of an Efficient Microfluidic Mixing System for } \\
\text { Generating Stabilized Polymeric Nanoparticles for } \\
\text { Controlled Drug Release }\end{array}$ & $\begin{array}{l}\text { Polymeric } \\
\text { nanoparticles }\end{array}$ & 2018 & 25 \\
\hline $\begin{array}{l}\text { Microfluidic Platform for Controlled Synthesis of } \\
\text { Polymeric Nanoparticles }\end{array}$ & $\begin{array}{l}\text { Polymeric } \\
\text { nanoparticles }\end{array}$ & 2008 & 26 \\
\hline $\begin{array}{l}\text { Microfluidic synthesis of highly potent limit-size lipid } \\
\text { nanoparticles for in vivo delivery of siRNA. }\end{array}$ & Lipid nanoparticles & 2012 & 27 \\
\hline $\begin{array}{l}\text { Zebrafish as a predictive screening model to assess } \\
\text { macrophage clearance of liposomes in vivo }\end{array}$ & Liposomes & 2019 & 28 \\
\hline $\begin{array}{l}\text { STAT3 inhibition specifically in human monocytes and } \\
\text { macrophages by CD163-targeted corosolic acid- } \\
\text { containing liposomes }\end{array}$ & Liposomes & 2019 & 29 \\
\hline $\begin{array}{l}\text { N-Oxy lipid-based click chemistry for orthogonal } \\
\text { coupling of mannan onto nanoliposomes prepared by } \\
\text { microfluidic mixing: Synthesis of lipids, } \\
\text { characterisation of mannan-coated nanoliposomes } \\
\text { and in vitro stimulation of dendritic cells }\end{array}$ & Liposomes & 2018 & 30 \\
\hline $\begin{array}{l}\text { Hyaluronic acid surface modified liposomes prepared } \\
\text { via orthogonal aminoxy coupling: synthesis of } \\
\text { nontoxic aminoxylipids based on symmetrically } \alpha \text { - } \\
\text { branched fatty acids }\end{array}$ & Liposomes & 2018 & 31 \\
\hline $\begin{array}{l}\text { mRNA-Lipid Nanoparticles: A potent tool for } \\
\text { manipulating neuronal genes }\end{array}$ & Lipid nanoparticles & 2017 & 32 \\
\hline $\begin{array}{l}\text { Microfluidic manufacturing improves polydispersity } \\
\text { of multicomponent polymeric nanoparticles }\end{array}$ & $\begin{array}{l}\text { Polymeric } \\
\text { nanoparticles }\end{array}$ & 2019 & 33 \\
\hline $\begin{array}{l}\text { Microfluidic preparation of PLGA microspheres as cell } \\
\text { carriers with sustainable Rapa release }\end{array}$ & $\begin{array}{l}\text { Polymeric } \\
\text { nanoparticles }\end{array}$ & 2019 & 34 \\
\hline $\begin{array}{l}\text { Microfluidic preparation of drug-loaded PEGylated } \\
\text { liposomes, and the impact of liposome size on } \\
\text { tumour retention and penetration }\end{array}$ & Liposomes & 2019 & 35 \\
\hline $\begin{array}{l}\text { Microfluidic-assisted nanoprecipitation of } \\
\text { (PEGylated) poly (d,I-lactic acid-co-caprolactone): } \\
\text { Effect of macromolecular and microfluidic } \\
\text { parameters on particle size and paclitaxel } \\
\text { encapsulation }\end{array}$ & $\begin{array}{l}\text { Polymeric } \\
\text { nanoparticles }\end{array}$ & 2018 & 36 \\
\hline $\begin{array}{l}\text { Design, production and optimization of solid lipid } \\
\text { microparticles (SLM) by a coaxial microfluidic device }\end{array}$ & $\begin{array}{l}\text { Solid lipid } \\
\text { microparticles }\end{array}$ & 2012 & 37 \\
\hline
\end{tabular}




\begin{tabular}{|l|l|l|l|}
\hline $\begin{array}{l}\text { Dynamic Pattern Formation in a Vesicle-Generating } \\
\text { Microfluidic Device }\end{array}$ & reverse micelles & 2001 & 38 \\
\hline $\begin{array}{l}\text { Synthesis of silver nanoparticles in a continuous flow } \\
\text { tubular microreactor }\end{array}$ & Silver nanoparticles & 2004 & 39 \\
\hline
\end{tabular}




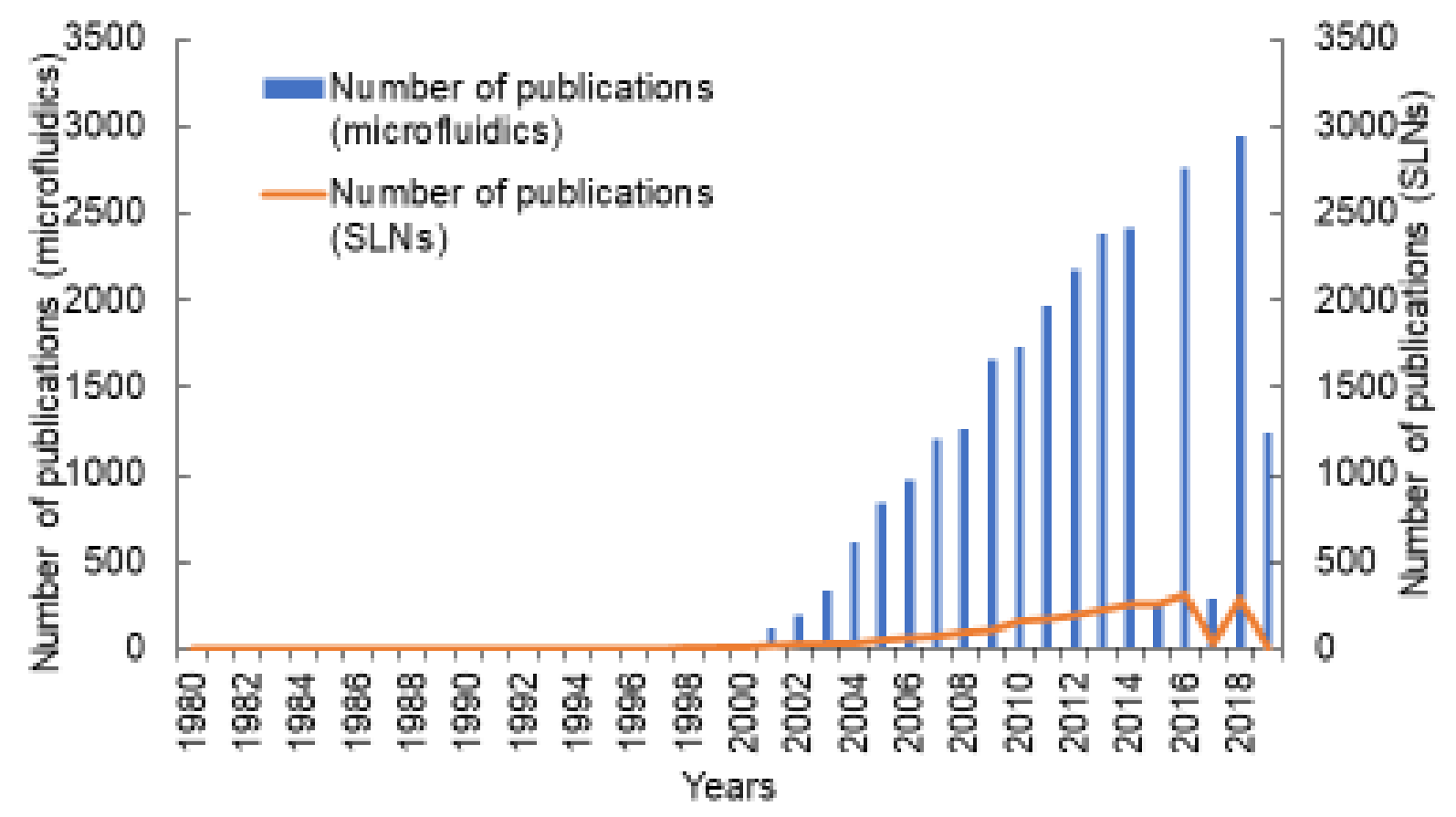

Figure 1. Microfluidic and solid lipid nanoparticles publications in engineering, multidisciplinary, and biology and medicine journals from 1980 to 2019. 
A)

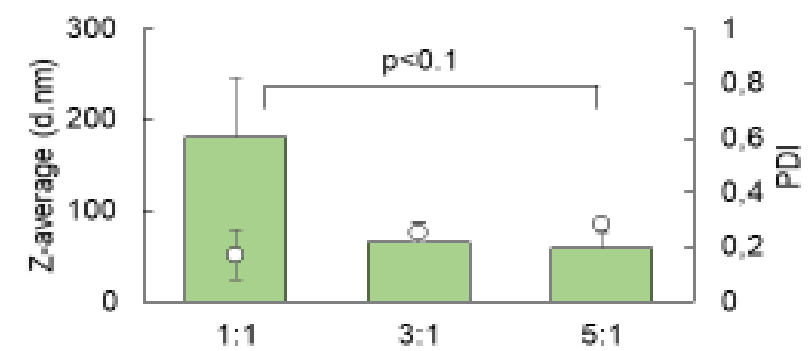

B)

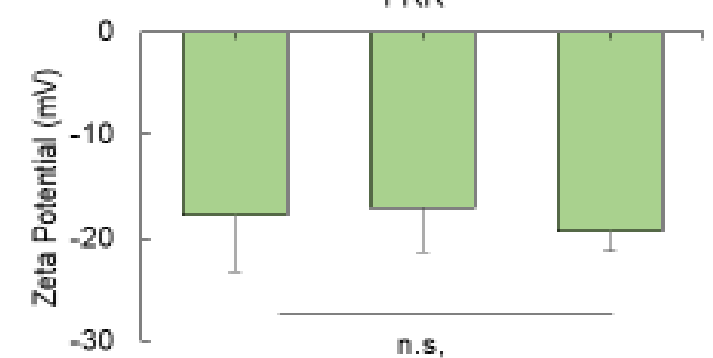

C)

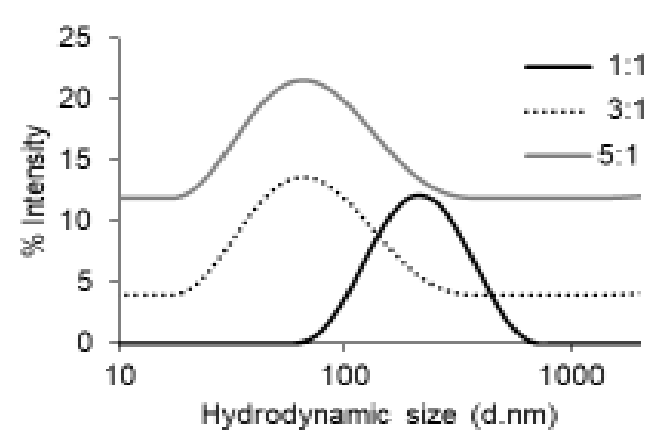

Figure 2. A) Size (columns) and PDI (dots) and B) Zeta-potential of Tristearin: mPEG-DSPE SLNs using Nanoassemblr after dialysis. Formulations with TFR 10 $\mathrm{mL} / \mathrm{min}$ and FRR from 1:1 to 5:1 had been tested. C) Intensity plot of SLNs made by Nanoassemblr and sized after dialysis purification method. D) Scanning Electron Microscopy image of Tristearin: mPEG-DSPE SLNs after dialysis made by Nanoassemblr. Formulations with TFR 10 mL/min and FRR 3:1 had been tested. Results are expressed as the means of three experiments \pm S.D. 

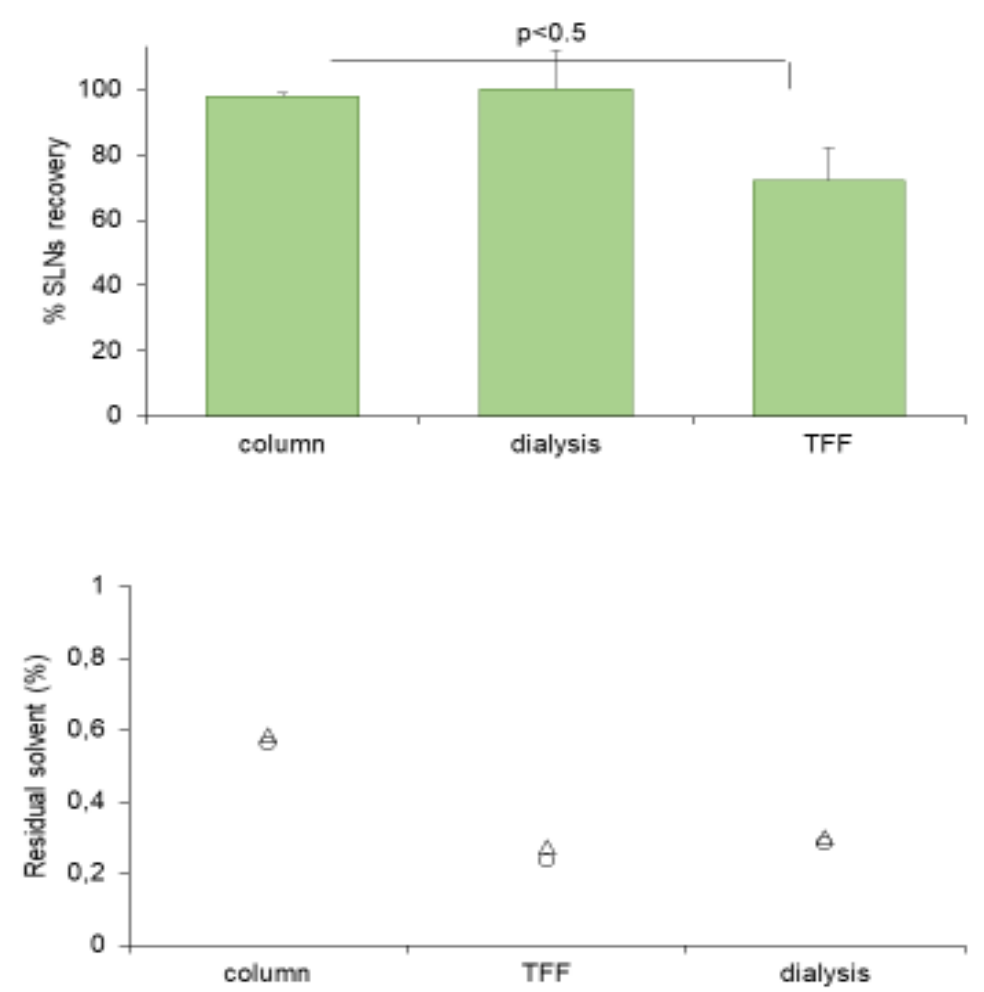

Figure 3. A) Size (columns) and PDI (dots) of Tristearin: mPEG-DSPE SLNs after spin column (black), dialysis (stripes) and TFF (grey) purification. Formulations with TFR $10 \mathrm{~mL} / \mathrm{min}$ and FRR from 1:1 to 5:1 had been tested. B) Zeta potential of Tristearin: mPEG-DSPE SLNs after spin column, dialysis and TFF purification. Formulations with TFR $10 \mathrm{~mL} / \mathrm{min}$ and FRR from 1:1 to 5:1 had been tested. C) Lipid recovery of Tristearin: $\mathrm{mPEG-DSPE} \mathrm{SLNs} \mathrm{after} \mathrm{spin} \mathrm{column,} \mathrm{dialysis} \mathrm{and}$ TFF purification. Formulations with TFR $10 \mathrm{~mL} / \mathrm{min}$ and FRR 1:1 had been tested. D) Residual solvent after spin column, dialysis and TFF expressed as percentage of remained ethanol ( $\mathrm{mL} \%)$. All data were normalised by IPA standard peaks area. Formulations with TFR $10 \mathrm{~mL} / \mathrm{min}$ and FRR 1:1 has been tested. 

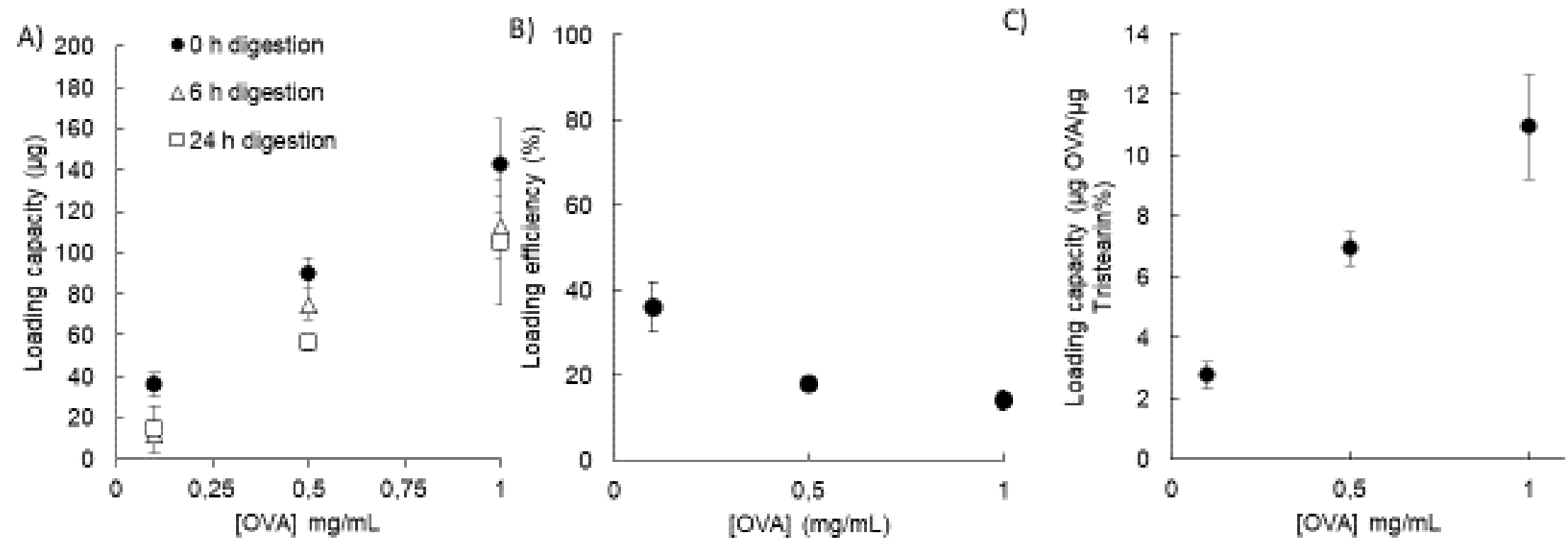

Figure 4 The effect of digestion method on entrapment. Solid lipid nanoparticles encapsulating $0.1,0.5$ and $1 \mathrm{mg} / \mathrm{mL}$ initial OVA content were formulated using the Nanoassemblr platform. A) Protein encapsulation efficiency was determined after 3 min, 6 hours and 24 hours post IPA digestion. Protein incorporation also expressed as B) Protein loading efficiency (\%) and C) Loading capacity (wt OVA/wt Tristearin). Results are expressed as the means of at least four experiments \pm SD. 

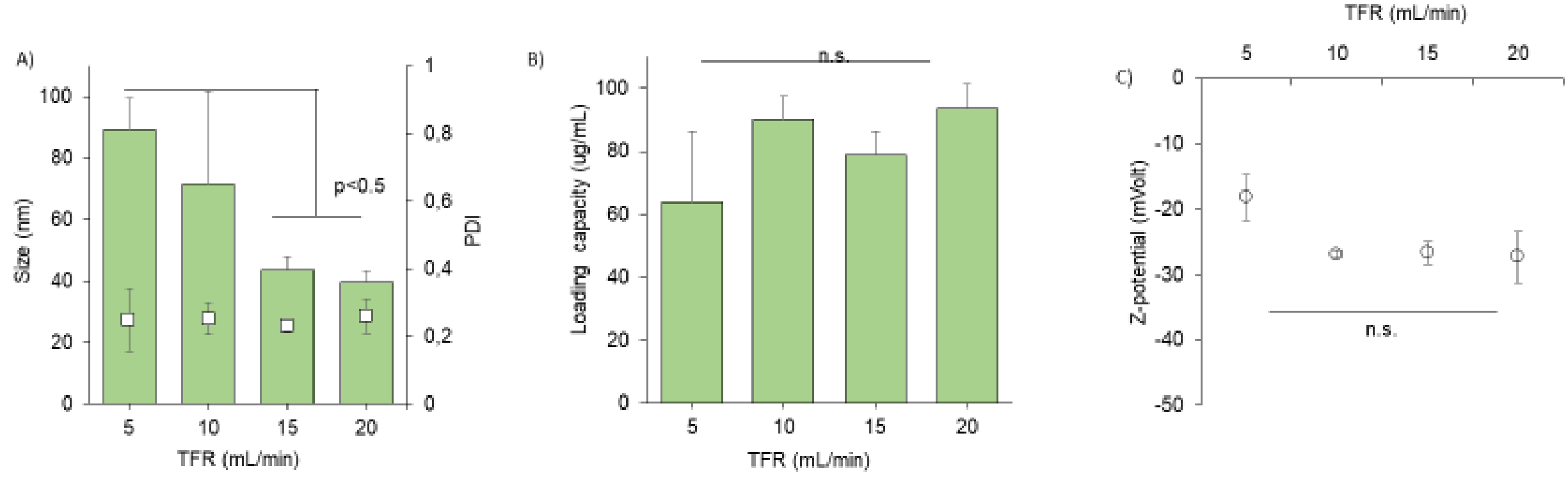

Figure 5. A) Size (columns), PDI (dots), B) Zeta potential and C) Loading capacity ( $\mu \mathrm{g} / \mathrm{mL}$ ) of OVA loaded SLNs. Initial protein concentration was $0.5 \mathrm{mg} / \mathrm{mL}$. FRR was set up at 3:1 while TFR were increased between 5 and $20 \mathrm{~mL} / \mathrm{min}$. Results are expressed as the means of at least four experiments \pm SD. 

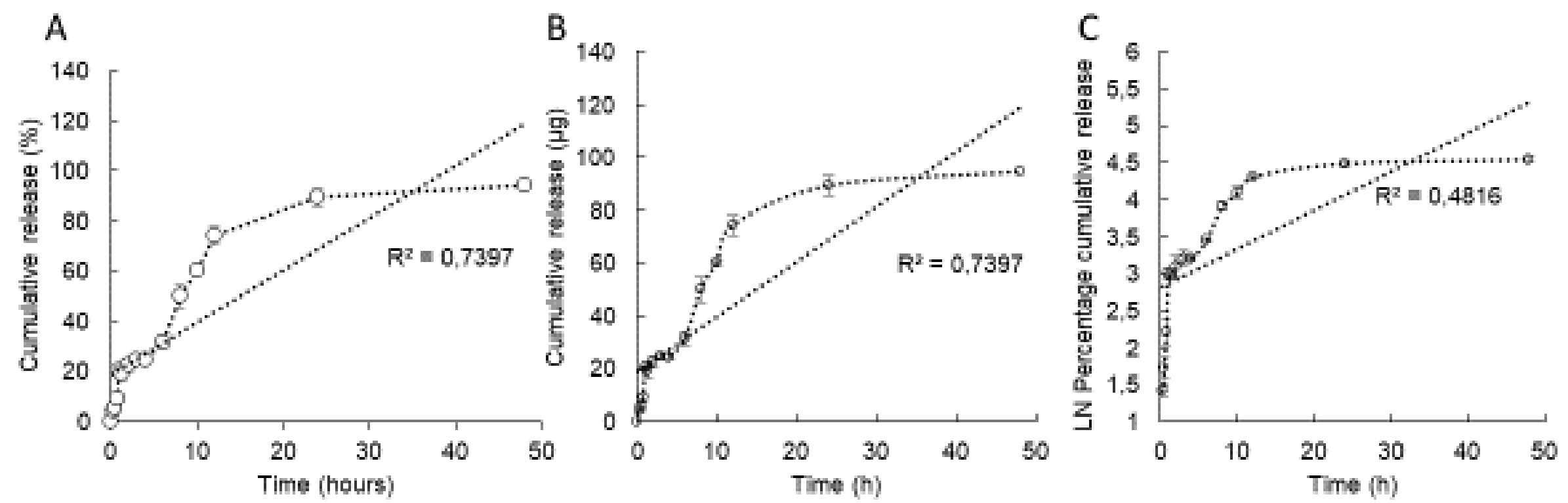

Figure 6 A) The cumulative release profile of OVA under physiological conditions from SLNs (PBS buffer, $\mathrm{pH}=7.4$, at $37^{\circ} \mathrm{C}$ ). Data was also replotted according to $B$ ) first-order and C) zero-order models. Results represent percentage cumulative release of initially incorporated OVA and are expressed as the means of three experiments \pm SD. 
speed from 5 to $10 \mathrm{~mL} / \mathrm{min}$ made no significant difference in particles size (between 70 and $90 \mathrm{~nm}$ ); however, enhancing TFR values to $15 \mathrm{~mL}$ per min or above reduced the particle sizes to a minimum of $40 \pm 4 \mathrm{~nm}$ without affecting samples homogeneity (around 0.25 ). The same trend was seen when particles surface charge was measured (Figure 5B) with the zeta potential at TFR $5 \mathrm{~mL} / \mathrm{min}$ being significantly less negative compared to ones at higher TFRs, where charge was maintained slightly negative (around $-30 \mathrm{mV}$ ). In respect to the loading efficiency, using an initial $0.5 \mathrm{mg} / \mathrm{mL}$ protein concentration, the capability was not significantly influenced by the total flow rate; however, less variability in protein loading was seen at flow rates of $10 \mathrm{mg} / \mathrm{mL}$ or more with loading of $80-90 \mu \mathrm{g} / \mathrm{mL}$ (Figure 5C).

\subsection{The effect of manufacturing on protein release kinetics}

The release profiles of OVA from SLNs produced was also investigated. To study this, particles were prepared from a FRR $3: 1$, TFR $10 \mathrm{~mL} / \mathrm{min}$ and OVA initial concentration of $0,5 \mathrm{mg} / \mathrm{mL}$. The results how that the SLNs give a rapid release of up to $90 \%$ within the first $24 \mathrm{~h}$ and the release does not follow a zero-order profile. The release was also plotted as $L n$ cumulative percentage of drug released vs time (Figure 6B) and the data suggests the release does not follow a first-order model. This finding suggested that a combination of more than one kinetics might drive protein release from SLNs.

\section{Discussion}

This work demonstrates that microfluidics technology can be employed as an alternative method for the rapid and scalable production of solid lipid nanoparticles containing hydrophilic molecules. Although there has been extensive work on delivery for hydrophobic molecules using SLNs (due to their lipid-based matrix facilitating drug incorporation) their applicability as water soluble carries has received less attention. Therefore, to consider this, we have investigated these systems for the delivery of water soluble proteins (ovalbumin). Our studies demonstrate that OVA-loaded SLNs can be manufactured with their particle size being process controlled. Previous studies on microfluidics confirmed the effect of flow rate ratio on particles dimensions, in agreement with what has been reported in the present work. ${ }^{(55-57)}$ For example, cationic 1,2-dioleoyl-3-trimethylammonium-propane (DOTAP) based liposomes formed at 1:5 solvent/aqueous formulation were smaller in size (50-75 nm) compared to the 1:1 solvent/aqueous formulation $(175-200 \mathrm{~nm})^{(5)}$. Furthermore, 1,2-distearoyl-snglycero-3-phosphocholine (DSPC) and cholesterol liposomes formed at low flow rate ratio (1:1) resulted to be larger in size $(200 \mathrm{~nm})$ with respect to their counterparts formulated at higher FRRs (around $90-120 \mathrm{~nm}$ ). ${ }^{(9)}$ However, it was also seen that increasing the FRR increased polydispersity; ${ }^{(6)}$ a possible explanation to this phenomenon would be related to the reduced particles fusion (Ostwald ripening) that occurred at higher FRR, due to the lower amount of residual solvent. Thus, the formation of smaller monodisperse particles in achieved. ${ }^{(58-59)}$ On the other hand, at higher FRRs, a dilution of the organic phase occurred, reducing the tendency of lipids to diffuse, with an effect on sample polydispersity; these observations were confirmed by previous studies where a staggered herringbone mixer was used ${ }^{(6)}$. The higher is the FRR the lower is the lipid concentration and consequently the lower is the rate of diffusion. This phenomenon led to partly incomplete nucleation and a lower rate of particles formation. ${ }^{(60)}$ 
When considering the surface charge of the SLN particles, zeta potential values remained unchanged along FRRs tested (around -20mV; Figure 2B) as expected; Tristearin or glyceryl tristearate is a triglyceride derived from three units of stearic acid, without any charged group at neutral $\mathrm{pH}$. ${ }^{\text {(61-63) }}$ However, PEG-DSPE is a linear phospholipid, a block copolymer of a hydrophobic part (DSPE) and a hydrophilic part (PEG). ${ }^{(64-65)}$ The phosphoethanolamine group is completely ionised at $\mathrm{pH} 7.4$, giving the PEG a net negative charge. By adding PEG-DSPE to SLNs formulation the distearoyl tail is incorporated to the tristearin solid layer; instead, the hydrophilic PEG-phosphoethanolamine part remained on lipid surface, making particles negatively charged. ${ }^{(66-68)}$ It is also known that the addition of PEG may help the manufacture of more homogeneous particles. ${ }^{(69)}$

In the development of manufacturing processes, production speed is important. Here we demonstrate that total flow rates of $20 \mathrm{~mL} / \mathrm{min}$ can easily be adopted with no effect on the particle size or protein loading. This is in line with previous work on liposomes, where increasing the flow rate from 10 to 20 $\mathrm{mL} / \mathrm{min}$ had no effect on liposome size, PDI or protein loading. ${ }^{(7)}$ Within the microfluidic cartridge, even although the surface to volume ratio is relatively high (due to the reduced dimensions of the channels), the Reynolds number ( $\mathrm{Re}=1 \rho \mathrm{v} / \eta$ ) of liquid is quite low (around 1$)^{(70-71)}$. In these conditions, the flow tends to be laminar and driven by diffusive forces, with a direct consequence on mixing process speed ${ }^{(72)}$. To overcome these issues, either the contact area or the contact time between solutions need to be enhanced. To address this, the inner geometry of the cartage plays an important role with the serpentine shape of the microchannel doubling the mixing efficiency of conventional straight microchannel ${ }^{(9)}$.

As part of the validation process, the residual ethanol concentration in the final product is one of the characteristics that must be considered. $\mathrm{ICH}$ guideline ${ }^{(73)}$ describes the validation parameters needed for a variety of analytical methods. According to the guideline, ethanol is a Class 3 solvent, which is considered less toxic and a lower risk solvent compared to Class 1 and 2 solvents and within pharmaceuticals levels of $50 \mathrm{mg}$ per day or less (corresponding to $5000 \mathrm{ppm}$ or $0.5 \%$ ) being acceptable would without justification. ${ }^{(74-75)}$. For laboratory production of SLNs, three methods were considered and both TFF and dialysis could remove solvents to below the required ICH levels (Figure 3). Whilst TFF was shown to give slightly lower recovery compared to the other methods, TFF offers faster and scalable purification options. Tangential flow filtration is a technique that utilizes a porous barrier to separate molecules in solution based on size or molecular weight. Application of pressure across a known pore size column drives the separation process. Smaller constituents pass through the barrier with the solvent as filtrate while the larger solutes are retained ${ }^{(76)}$. In this technique the feed stream passes parallel to the membrane face as one portion passes through the membrane (permeate) while the remainder (retentate) is recirculated back to the feed reservoir. (77) TFF has already been demonstrated for the purification of other nanomedicines, for example, poly-vinyl alcohol (PVA) and sodium cholate were shown to be efficiently removed from monomethoxy poly (ethylene glycol) poly ( $\mathrm{D}$, L-lactide-co-glycolide) (mPEG-PLGA) co-polymer nanoparticles using TFF, without altering particles properties. ${ }^{(78)}$ Furthermore, tangential flow filtration was applied as purification method for Poly (d, I-lactic acid) nanoparticles from poloxamer 188; within this study the authors reported that purification of the nanoparticles from the excess surfactant using tangential flow filtration enabled even better drying results when the different sugars were studied. ${ }^{(79)}$

Considering protein loading within solid lipid nanoparticles, drug loading via microfluidics is a passive mechanism, where a simultaneous dispersion of drug and lipids in the aqueous phase occurs and 
microfluidics can promote higher encapsulation efficiency compared to conventional techniques. Herein, we achieved high protein (OVA) loading even at lower OVA doses (around $40 \% \mathrm{LE}$ at $0,1 \mathrm{mg} / \mathrm{mL}$ initial [OVA]) (Figure 4 and 5). This is higher than commonly reported for SLNs manufactured by other methods. For example, it has been seen that egg lecithin and stearic acid based SLNs made through warm microemulsion were able to encapsulate below $5 \%$ of the water soluble immunostimulant Thymopentin ${ }^{(80)}$. The same technique was applied for cyclosporine loading into SLNs made of a mixture of stearic acid and Epikuron $200^{\circledR}$. However, the loading efficiency was not promising (just $13 \%)^{(81)}$. Further, supercritical fluids (e.g. $\mathrm{CO}_{2}$ ) were applied to SLN manufacturing. However, many papers reported that the entrapment efficiency of small peptides - e.g. Insulin - within Tristearin based SLNs was very low $(<3 \%)^{(82-83)}$. This improved loading via microfluidics has also been shown with other nanoparticle systems, for example, 1,2-distearoyl-sn-glycero-3-phosphocholine (DSPC) and cholesterol liposomes made by microfluidics gave $30 \%$ proteins loading $(0.18 \mathrm{mg} / \mathrm{mL}$ initial OVA concentration). This is in comparison to below $5 \%$ with lipid hydration and extrusion or sonication. ${ }^{(7)}$ Furthermore, the concentration of sulforhodamine B in liposomes prepared with microfluidics was found to be unexpectedly high due to a spatial concentration enhancement induced by viscosity anisotropy in the microchannel. ${ }^{(84-85)}$ Therefore, the combination of the fast production step and higher entrapment efficiency of protein proved the suitability of microfluidics as effective alternative method for protein loaded solid lipid nanoparticles. In terms of release from the SLNs (Figure 6), the majority of the protein was released within $24 \mathrm{~h}$. This initial fast release of OVA maybe resulting from OVA associated at the surface layer of the solid lipid nanoparticles ${ }^{\left({ }^{86}\right)}$ and the PEG coating on SLNs surface could accelerate the release of proteins or drugs from lipid matrix. It has been seen ${ }^{\left({ }^{83)}\right.}$ that PEGylated particles showed a faster protein release with an initial burst, probably due to protein

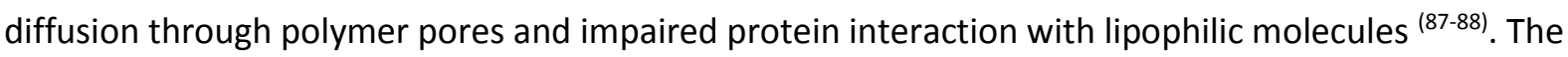
release profile of OVA from the SLNs may be of advantage in the delivery of antigens with the initial fast release facilitating the immune system priming while the slow released OVA would prolong the immune system stimulation. This mechanism is called "depot effect" and it was seen to be desirable for many vaccines candidates. For example, it was demonstrated that a long-term retention and slow release of different cationic liposomes (containing either Dimethyldioctadecylammonium (DDA), $3_{\beta^{-}}$ $\mathrm{N}$-(N', N'-Dimethylaminoethane) carbomyl] Cholesterol (DC-Chol), or 1,2-Dioleoyl-3trimethylammonium Propane (DOTAP)) and vaccine antigen from the injection site appears favorable for a stronger Th1 immune response. ${ }^{\left({ }^{89-90)}\right.}$

\section{Conclusions}

In this paper, microfluidics was demonstrated to be a scalable and high-throughput manufacturing method for both empty and protein loaded solid lipid nanoparticles preparation. Particles physicochemical attributes were confirmed to be suitable for pre-clinical and clinical application. Furthermore, using microfluidics method it was possible to combine particles manufacturing and drug encapsulation in a single process step, with evident benefits for time for production

\section{Acknowledgements}

This work was funded by the European Commission Project Leveraging Pharmaceutical Sciences and Structural Biology Training to Develop 21st Century Vaccines (H2020-MSCA-ITN-2015 grant agreement 675370). 


\section{Supporting information Available}

Data presented in this publication can be found at DOI 10.2174/2210303109666190807104437

\section{References}

[1] Whitesides, G.M., 2006. The origins and the future of microfluidics. Nature 442, 368-373 [2] Bjork S.M. Joensson H.N. Microfluidics for cell factory and bioprocess development. Current Opinion in Biotechnology 2019, 55:95-102

[3] Geoffrey S. The Development of a Low-Cost Microfluidic Magnetic Separation System. 2015-0313T01:05:59Z

[4] Squires, T.M., Quake, S.R., 2005. Microfluidics: fluid physics at the nanoliter scale. Rev. Modern Phys.(2005) 77, 977

[5] Kastner E., Kaur R.,Lowry D., Moghaddam B., Wilkinson A., Perrie Y. High-throughput manufacturing of size-tuned liposomes by a new microfluidics method using enhanced statistical tools for characterization. International Journal of Pharmaceutics 477 (2014) 361-368

[6] Kastner E., Verma V., Lowry D., Perrie Y. Microfluidic-controlled manufacture of liposomes for the solubilisation of a poorly water soluble drug. International Journal of Pharmaceutics 485 (2015) 122130

[7] Forbes, N., Hussain, M. T., Briuglia, M. L., Edwards, D. P., ter Horst, J. H., Szita, N., \& Perrie Y. Rapid and scale-independent microfluidic manufacture of liposomes entrapping protein incorporating inline purification and at-line size monitoring. International Journal of Pharmaceutics, (2019) 556, 6881.

[8] Dimov N., Kastner E., Hussain M., Perrie Y. Szita N. Formation and purification of tailored liposomes for drug delivery using a module-based micro continuous-flow system. Scientific Report, 12045 (2017)

[9] Joshi S., Hussain M.T., Roces C.B., Anderluzzi G., Kastner E., Salmaso S., Kirby D.J., Perrie Y. Microfluidics based manufacture of liposomes simultaneously entrapping hydrophilic and lipophilic drugs. International Journal of Pharmaceutics, (2015) 514 (1). 160-168

[10] Pradhan, P., Guan, J., Lu, D., Wang, P.G., Lee, L.J., Lee, R.J., 2008. A facile microfluidic method for production of liposomes. Anticancer Res. (2008) 28, 943-947.

[11] Pihl J, Karlsson M, Chiu DT. Microfluidic technologies in drug discovery. Drug Discov Today (2005); 10: $1377-83$.

[12] Beebe, D. J., Mensing, G. A. \& Walker, G. M. Physics and application of microfluidics in biology. Annu. Rev. Biomed. Eng. (2002) 4, 261-286.

[13] Jahn, A., Stavis, S.M., Hong, J.S., Vreeland, W.N., DeVoe, D.L., Gaitan, M. Microfluidic mixing and the formation of nanoscale lipid vesicles. ACS Nano (2010) 4, 2077-2087. 
[14] Mazutis L., Vasiliauskas R., Weitz D. A. Microfluidic Production of Alginate Hydrogel Particles for Antibody Encapsulation and Release. Macromol. Biosci.(2015), 15, 1641-1646

[15] Amoyav B., Benny O., Controlled and tunable polymer particles' production using a single microfluidic device. Applied Nanoscience (2018) 8:905-914

[16] C. Zhang, X. Zhang, W. Zhao, C. Zeng, W. Li, B. Li, X. Luo, J. Li, J. Jiang, B. Deng, D.W. McComb, Y. Dong. Chemotherapy drugs derived nanoparticles encapsulating mRNA encoding tumor suppressor proteins to treat triple-negative breast cancer. Nano Res. 2019, 12(4): 855-861

[17] R. Jain, JP. Frederick, EY. Huang, KE. Burke, DM. Mauger, EA. Andrianova, SJ. Farlow, S. Siddiqui, J. Pimentel, K. Cheung-Ong, KM. McKinney, C. Köhrer, MJ. Moore, and T. Chakraborty. MicroRNAs Enable mRNA Therapeutics to Selectively Program Cancer Cells to Self-Destruct. Nucleic Acid Ther (2018) 28(5):285-296

[18] J. Finn, A. Smith, M. Patel, L. Shaw, M. Youniss, J. Heteren, T. Dirstine, C. Ciullo, R. Lescarbeau, J. Seitzer, R. Shah, A. Shah, D. Ling, J. Growe, M. Pink, E. Rohde, K. Wood, W. Salomon, W. Harrington, C. Dombrowski, W. Strapps, Y. Chang, D. Morrissey . A Single Administration of CRISPR/Cas9 Lipid Nanoparticles Achieves Robust and Persistent In Vivo Genome Editing. Cell Reports (2018) 22, 22272235

[19] Carugo D., Bottaro E., Owen J., Stride E., Nastruzzi C. Liposome production by microfluidics: potential and limiting factors. ScientificRepoRts (2016) 6:25876

[20] Sá Correia M.G., Briuglia M.L., Niosi F. Lamprou D.A. Microfluidic manufacturing of phospholipid nanoparticles: Stability, encapsulation efficacy, and drug release. International Journal of Pharmaceutics. (2017) 516 (1-2) 0378-5173.

[21] Ran R., Middelberg A. P. J., Zhao C.X. Microfluidic synthesis of multifunctional liposomes for tumour targeting. ColloidsandSurfacesB:Biointerfaces 148(2016)402-410

[22] Y. Zhang, H. Tan, J.D. Daniels, F. Zandkarimi, H. Liu, L.M. Borwn, K. Uchida, O.A. O'Connor. B.R. Stockwell. Imidazole Ketone Erastin Induces Ferroptosis and Slows Tumor Growth in a Mouse Lymphoma Model. Cell Chemical Biology (2019) 26, 1-11

[23] Thomas A., Garg S.M., De Souza R.A.G., Ouellet E., Tharmarajah G., Reichert D., Ordobadi M., Ip S., Ramsay E.C. Microfluidic Production and Application of Lipid Nanoparticles for Nucleic Acid Transfection. Multiple Myeloma (2018) 978-1-4939-7865-6

[24] M Yu, L Xu, F Tian, Q Su, N Zheng, Y Yang. Rapid transport of deformation-tuned nanoparticles across biological hydrogels and cellular barriers. Nature Communications (2018) 2041-1723

[25] Y Morikawa, T Tagami, A Hoshikawa, T Ozeki. The Use of an Efficient Microfluidic Mixing System for Generating Stabilized Polymeric Nanoparticles for Controlled Drug Release. Biol. Pharm. Bull. 41, 899-907 (2018) 899

[26] Karnik R., Gu F., Basto P., Cannizzaro C., Dean L., Kyei-Manu W., Langer R. Farokhzad O.C. Microfluidic Platform for Controlled Synthesis of Polymeric Nanoparticles . Nano Lett. (2008) 8, 9, 2906-2912

[27] Belliveau, N.M., Huft, J., Lin, P.J., Chen, S., Leung, A.K., Leaver, T.J., Wild, A.W., Lee, J.B., 
Taylor, R.J., Tam, Y.K., 2012. Microfluidic synthesis of highly potent limit-size lipid nanoparticles for in vivo delivery of siRNA. Mol. Ther. Nucleic Acids. (2012) 10.1038

[28] S. Sieber, P. Grossen, P. Uhl, P. Detampel, W. Mier, D. Witzigmann, J. Huwyler. Zebrafish as a predictive screening model to assess macrophage clearance of liposomes in vivo. Nanomedicine: Nanotechnology, Biology, and Medicine 17 (2019) 82-93

[29] MN Andersen, A Etzerodt, JH Graversen, LC Holthof, SK Moestrup, M Hokland, HJ Møller. STAT3 inhibition specifically in human monocytes and macrophages by CD163-targeted corosolic acidcontaining liposomes. Cancer Immunology, Immunotherapy (2019) 68:489-502

[30] Bartheldyová E., Knotigová P.T., Zachová K., Mašek J., Kulich P., Effenberg R., Zyka D., Hubatka F., Kotouček J., Čelechovská H., Héžová R., Tomečková A., Mašková E., Fojtíková M., Macaulay S., Bystrický P., Paulovičová L., Paulovičová E., Drož L., Ledvina M., Raška M., Turánek J. N-Oxy lipid-based click chemistry for orthogonal coupling of mannan onto nanoliposomes prepared by microfluidic mixing: Synthesis of lipids, characterisation of mannan-coated nanoliposomes and in vitro stimulation of dendritic cells. Carbohydrate Polymers 207 (2019) 521-532

[31] Bartheldyová E., Effenberg R., Mašek J., Procházka L., Knötigová P.T., Kulich P., Hubatka F., Velínská K., Zelníčková J., Zouharová D., Fojtíková M., Hrebík D., Plevka P., Mikulík R., Miller A.D., Macaulay S., Zyka D., Drož L., Raška M., Ledvina M., Turánek J. Hyaluronic acid surface modified liposomes prepared via orthogonal aminoxy coupling: synthesis of nontoxic aminoxylipids based on symmetrically $\alpha$-branched fatty acids. Bioconjugate Chem. (2018) 29, 7, 2343-2356

[32] G. Heuck, R. DeSouza, A. Thomas, I. Backstrom, S.M. Garg, E. Ouellet, J. Singh, S. Chang, K. Marshall, P. Johnson, M. DeLeonardis, A. Armstead, G. Tharmarajah, S. Ip, T.J. Leaver, A.W. Wild, R.J. Taylor and E.C. Ramsay. mRNA-Lipid Nanoparticles: A potent tool for manipulating neuronal genes. Vaccines Vaccin (2017) 2041-1723

[33] Abstiens K., Goepferich A.M. Microfluidic manufacturing improves polydispersity of multicomponent polymeric nanoparticles. Journal of Drug Delivery Science and Technology 49 (2019) 433-439

[34] Zhu C., Yang H., Shen L., Zheng Z., Zhao., Li Q., Yu F., Cen L.Microfluidic preparation of PLGA microspheres as cell carriers with sustainable Rapa release. J Biomater Sci Polym Ed. (2019) 09205063

[35] Dong YD., Tchung E., Nowell C., Kaga S., Leong N., Mehta D., Kaminskas LM., Boyd BJ. Microfluidic preparation of drug-loaded PEGylated liposomes, and the impact of liposome size on tumour retention and penetration. J Liposome Res. (2019) 0898-2104

[36] Lallana E., Donno R., Magrì D., Barker K., Nazir Z., Treacher K., Lawrence MJ., Ashford M., Tirelli N. Microfluidic-assisted nanoprecipitation of (PEGylated) poly (d,I-lactic acid-co-caprolactone): Effect of macromolecular and microfluidic parameters on particle size and paclitaxel encapsulation. International Journal of Pharmaceutics 548 (2018) 530-539

[37] Capretto L., Mazzitelli S., Nastruzzi C. Design, production and optimization of solid lipid microparticles (SLM) by a coaxial microfluidic device. Journal of Controlled Release 160 (2012) 409417 
[38] Thorsen T., Roberts R.W., Arnold F.H., Quake S.R. Dynamic Pattern Formation in a VesicleGenerating Microfluidic Device. Phys. Rev. Lett. (2001), 86, 4163.

[39] Lin XZ, Terepka AD, Hong Y (2004) Synthesis of silver nanoparticles in a continuous flow tubular microreactor. Nano Lett (2004) 4(11):2227-2232

[40] van Swaay, D. Microfluidic methods for forming liposomes. Lab Chip (2013) 13, 752-767.

[41] 5) M.D. Joshi, R.H. Müller, Lipid nanoparticles for parenteral delivery of actives,Eur. J. Pharm. Biopharm. 71 (2) (2009) 161-172

[42] S.S. Shidhaye, R. Vaidya, S. Sutar, A. Patwardhan, V.J. Kadam, Solid lipid nanoparticles and nanostructured lipid carriers - innovative generations of solid lipid carriers, Curr. Drug Deliv. 5 (4) (2008) 24-331.

[43] S.A. Wissing, O. Kayser, R.H. Müller, Solid lipid nanoparticles for parenteral drug delivery, Adv. Drug Deliv. Rev. 56 (9) (2004) 1257-1272.

[44] H.R. Kim, I.K. Kim, K.H. Bae, S.H. Lee, Y. Lee, T.G. Park, Cationic solid lipid nanoparticles reconstituted from low density lipoprotein components for delivery of siRNA, Mol. Pharm. 5 (4) (2008) 622-631.

[45] J. Weiss, E.A. Decker, D.J. McClements, K. Kristbergsson, T. Helgason, T. Solid lipid nanoparticles as delivery systems for bioactive food components.Food Biophysics, 3 (2008) 1557-1866

[46] M.A. Cerqueira, A.C. Pinheiro, H.D. Silva, P.E. Ramos, M.A. Azevedo, M.L. Flores-López, Rivera M.C., Bourbon A.I., Ramos O.L.,A.A. Vicente. Design of bio-nanosystems for oral delivery of functional compounds. Food Engineering Reviews, (2014) 1866-7910

[47] Stelzner J.J. Behrens M. Behrens S. Mäder K. Squalene containing solid lipid nanoparticles, a promising adjuvant system for yeast vaccines. Vaccine 36 (2018) 2314-2320

[48] Olbrich, C., Mueller, R.H., Tabatt, K., Kayser, O., Schulze, C. and Schade, R. Stable biocompatible adjuvants--a new type of adjuvant based on solid lipid nanoparticles: a study on cytotoxicity, compatibility and efficacy in chicken. Altern. Lab. Anim., (2002) 30(4): 443-58

[49] G. Chen, S. Zeng, H. Jia, X. He, Y. Fang, Z. Jing. Adjuvant effect enhancement of porcine interleukin2 packaged into solid lipid nanoparticles Res. Vet. Sci., 96 (2014) 62-68

[50] Almelda AJ, Souto E. Solid lipid nanoparticles as a drug delivery system for peptides and proteins. Adv. Drug Deliv. Rev. (2007) 59:478-490

[51] Xie SY, Wang SL, Zhao BK, Han C, Wang M, Zhou WZ. Effect of PLGA as a polymeric emulsifier on preparation of hydrophilic protein-loaded solid lipid nanoparticles. Colloids Surf. B. (2008) 67:199-204

[52] Sjöström B, Bergenståhl B. Preparation of submicron drug particles in lecithin-stabilized o/w emulsions I. Model studies of the precipitation of cholesteryl acetate. Int. J. Pharm. (1992) 88:53-62

[53] Saraf S, Mishra D, Asthana A, Jain R, Singh S, Jain NK. Lipid microparticles for mucosal immunization against hepatitis B. Vaccine. (2006) 24:45-56

[54] Muller RH, Radtke M, Wissing SA. Nanostructured lipid matrices for improved microencapsulation of drugs. Int. J. Pharm. (2002) 242 (1-2):121-8 
[55] Maeki, M., Saito, T., Sato, Y., Yasui, T., Kaji, N., Ishida, A., Tani, H., Baba, Y., Harashima, H., Tokeshi, M. A strategy for synthesis of lipid nanoparticles using microfluidic devices with a mixer structure. RSC Adv. (2015) 5, 46181-46185.

[56] Patra, M., Salonen, E., Terama, E., Vattulainen, I., Faller, R., Lee, B.W., Holopainen, J., Karttunen, $M$. Under the influence of alcohol: the effect of ethanol and methanol on lipid bilayers. Biophys. J. (2006) 90, 1121-1135.

[57] Jahn, A., Stavis, S.M., Hong, J.S., Vreeland, W.N., DeVoe, D.L., Gaitan, M. Microfluidic mixing and the formation of nanoscale lipid vesicles. ACS Nano (2010) 4, 2077-2087.

[58] 26) Zhigaltsev, I.V., Belliveau, N., Hafez, I., Leung, A.K., Huft, J., Hansen, C., Cullis, .R.P. Bottom-up design and synthesis of limit size lipid nanoparticle systems with aqueous and triglyceride cores using millisecond microfluidic mixing. Langmuir (2012) 28, 3633-3640

[59] Zook, J.M., Vreeland, W.N. Effects of temperature, acyl chain length, and Flow rate ratio on liposome formation and size in a microfluidic hydrodynamic focusing device. Soft Matter (2010) 6, 1352-1360.

[60] Balbino, T.A., Azzoni, A.R., de La Torre, L.G. Microfluidic devices for continuous production of pDNA/cationic liposome complexes for gene delivery and vaccine therapy. Colloid Surf. B (2013) 111, 203-210

[61] Mehnert W, Mader K. Solid Lipid Nanoparticles - Production, Characterization and Applications. Adv Drug Delivery Rev. (2001) 47:165-196.

[62] Xue HY, Wong HL. Tailoring Nanostructured Solid-Lipid Carriers for Time-Controlled Intracellular siRNA Kinetics to Sustain RNAi-Mediated Chemosensitizationd. Biomaterials. (2011) 32:2662-2672.

[63] Wissing SA, Kayser O, Muller RH. Solid Lipid Nanoparticles for Parenteral Drug Delivery. Advanced Drug Delivery Reviews. (2004) 56:1257-1272.

[64] Wang R., Xiao R., Zeng Z.,Xu L., Wang J. Application of poly(ethylene glycol)distearoylphosphatidylethanolamine (PEG-DSPE) block copolymers and their derivatives as nanomaterials in drug delivery. Int J Nanomedicine. (2012) 7: 4185-4198.

[65] Wu H.,Zhu L.,Torchilin V.P. pH-sensitive poly(histidine)-PEG/DSPE-PEG co-polymer micelles for cytosolic drug delivery. Biomaterials. (2013) 34(4): 1213-1222.

[66] Lobovkina, T., Jacobson, G. B., Gonzalez-Gonzalez, E., Hickerson, R. P., Leake, D., Kaspar, R. L., H. Contag C.H., Zare, R. N. In vivo sustained release of siRNA from solid lipid nanoparticles. ACS nano. (2011) 5(12), 9977-9983.

[67] Uner, M., \& Yener, G. Importance of solid lipid nanoparticles (SLN) in various administration routes and future perspectives. International journal of nanomedicine. (2007) 2(3), 289-300.

[68] Kashanian S. Rostami E. PEG-stearate coated solid lipid nanoparticles as levothyroxine carriers for oral administration. J Nanopart Res (2014) 16:2293

[69] Bahl, K., Senn, J.J., Yuzhakov, O., Bulychev, A., Brito, L.A., Hassett, K.J., Laska, M.E., Smith, M., Almarsson, Ö., Thompson, J., et al. (2017). Preclinical and clinical demonstration of immunogenicity by mRNA vaccines against H10N8 and H7N9 influenza viruses. Mol. Ther.(2017) 25, 1316-1327. 
[70] Lam Y, Gan H, Nguyen N, Lie H. Micromixer based on viscoelastic flow instability at low Reynolds number. Biomicrofluid. (2009) 3:014106

[71] Huang MZ, Yang RJ, Tai CH, Tsai CH, Fu LM. Application of electrokinetic instability flow for enhanced micromixing in cross-shaped microchannel. Biomed. Microdevices. (2006) 8:309-315

[72] Meijer HEH, Singh MK, Kang TG, den Toonder JMJ, Anderson PD. Passive and active mixing in microfluidic devices. Macromol. Symp. (2009)279:201-209.

[73] ICH. Harmonized tripartite guideline, Q3C impurities: residual solvents. Fed Reg (1997)62:67377.

[74] Klok R.P., Windhorst A.D. Residual solvent analysis by gas chromatography in radiopharmaceutical formulations containing up to $12 \%$ ethanol. Nuclear Medicine and Biology 33 (2006) 935-938

[75] Qin L, Hu CQ, Yin LH. Establishment of a knowledge base for prescreening residual solvents in pharmaceuticals. Chromatographia (2004) 59:475-80.

[76] Schwartz L. Desalting and Buffer Exchange by Dialysis, Gel Filtration, or Diafiltration. Pall Life Sciences.

[77] Schwartz L., Seeley K. Introduction to Tangential Flow Filtration for Laboratory and Process Development Applications. Pall Life Sciences

[78] Dalwadi G., Sunderland V. Purification of PEGylated Nanoparticles Using Tangential Flow Filtration (TFF). Drug Development and Industrial Pharmacy,(2007) 33:9, 1030-1039.

[79] Hirsjärvi S., Peltonen L.,Hirvonen J. Effect of Sugars, Surfactant, and Tangential Flow Filtration on the Freeze-Drying of Poly(lactic acid) Nanoparticles. AAPS PharmSciTech. (2009) 10(2): 488-494.

[80] S. Morel, E. Ugazio, R. Cavalli, M.R. Gasco, Thymopentin in solid lipid nanoparticles, Int. J. Pharm. 132 (1996) 259-261

[81] E. Ugazio, R. Cavalli,M.R. Gasco, Incorporation of cyclosporine A in solid lipid nanoparticles (SLN), Int. J. Pharm. 241 (2002) 341-344

[82] Salmaso, Bersani S., Elvassore N., Bertucco A., Caliceti P. Biopharmaceutical characterisation of insulin and recombinant human growth hormone loaded lipid submicron particles produced by supercritical gas micro-atomisation. International Journal of Pharmaceutics 379 (2009) 51-58

[83] Salmaso, Elvassore N., Bertucco A., Caliceti P Production of solid lipid submicron particles for protein delivery using a novel supercritical gas-assisted melting atomization process. Journal of Pharmaceutical Sciences. 10 (2009) 1002

[84] Jahn, A., Reiner, J., Vreeland, W., DeVoe, D., Locascio, L., Gaitan, M. Unexpectedly high entrapment efficiencies in nanometer scale liposomes with hydrodynamic focusing using continuousflow microfluidics. Twelfth International Conference on Miniaturized Systems for Chemistry and Life Sciences . (2008) 978-0-9798064

[85] A. Jahn, W.N. Vreeland, D.L. DeVoe, L.E. Locascio, M. Gaitan., Microfluidic directed formation of liposomes of controlled size, Langmuir, (2007) 23 (11), 6289-6293. 
[86] Wilson B., Samanta M.K., Santhi K., Kumar K.P.S., Paramakrishnan N., Suresh B.; Poly(nbutylcyanoacrylate) nanoparticles cated with polysorbate 80 for the targeted delivery of rivastigmine into the brain to treat Alzheimer's disease. Brain Research, (2008)

[87] Liu J, Gong T, Wang C, Zhong Z, Zhang Z. Solid lipid nanoparticles loaded with insulin by sodium cholate-phosphatidylcholine-based mixed micelles: preparation and characterization. Int. J. Pharm. (2007) 340:153-162

[88] Zhang X.,Chen G.,Zhang T., Ma Z., Wu B. Effects of PEGylated lipid nanoparticles on the oral absorption of one BCS II drug: a mechanistic investigation. Int J Nanomedicine. (2014) 9: 5503-5514.

[89] Lacey M.,Christensen D., Bramwell V.D.,Lindenstrøm T.,Agger E.M.,Andersen P., Perrie Y. Comparison of the Depot Effect and Immunogenicity of Liposomes Based on Dimethyldioctadecylammonium (DDA), 3 -[N-( $\mathrm{N}^{\prime}, \mathrm{N}^{\prime}$-Dimethylaminoethane)carbomyl] Cholesterol (DC-Chol), and 1,2-Dioleoyl-3-trimethylammonium Propane (DOTAP): Prolonged Liposome Retention Mediates Stronger Th1 Responses. Mol. Pharm (2011) 7;8(1):153-61

[90] Lacey M , Bramwell V. Christensen D., Agger E.M. , Andersen P., Perrie Y.Liposomes based on dimethyldioctadecylammonium promote a depot effect and enhance immunogenicity of soluble antigen. Journal of Controlled Release 142 (2010) 180-186 
